\title{
Relationship of Colorectal Polyps and Fatty Liver Disease Diagnosed by Ultrasonography
}

\author{
Hye-Nam Lee ${ }^{1,2}$, Cheong-Hwan Lim ${ }^{1}$, Hong-Ryang Jung ${ }^{1}$ \\ Dept. of Health Care, Hanseo University ${ }^{1}$ \\ Dept. of Radiotechnology, Wonkwang Health Science University ${ }^{2}$

\section{초음파로 진단된 지방간 질환과 대장 용종과의 연관성} \\ 이혜남 ${ }^{1,2}$, 임청환 ${ }^{1}$, 정홍량 $^{1}$ \\ 한서대학교 보건의료학과 ${ }^{1}$ \\ 원광보건대학교 방사선과 ${ }^{2}$
}

\begin{abstract}
This study proposes a more comprehensive approach for FLD by analyzing the relationship of colorectal polyps, which are precursors of colorectal cancer. In Chi-Square tests of FLD and colorectal polyps, the prevalence of colorectal polyps was significantly high in cases of FLD. The polyps and correlation of each factor showed a positive relationship with all factors, and the correlation coefficient with FLD was highest $(\mathrm{r}=$ $0.39, \mathrm{p}<.001$ ). In multiple regression analysis, FLD(OR 3.80 95\% CI 1.93.-7.50), FBS (OR 2.51; 95\% CI 1.12-5.62), and older age (OR 2.12; 95\% CI 1.27-3.54) were independent risk factors for colorectal polyps. FLD was associated with the prevalence of colorectal polyps. These results show a meaningful influenceof FLD by ultrasonography in the occurrence of colorectal polyps, and that positive consideration of colonoscopy is needed for diagnosed FLD.
\end{abstract}

Key Words : Ultrasonography, Colorectal Polyp, Fatty Liver Disease, Colonoscopy, Colon cancer

요 약 지방간은 초음파검사에 의해 진단되는 임상적으로 흔한 간질환이다. 본 연구에서는 지방간과 대장암의 전구 병변인 대장용종과의 연관성을 분석하여 지방간에 대한 보다 포괄적인 접근방법을 제시하고자 한다. 2012년부터 2013년 1년 동안 청주소재 소화기내과전문센터에서 복부초음파와 대장내시경검사를 동시에 시행한 만성간질환이나 대장질환이 없는 성인 348 명을 대상으로 하였다. 지방간과 대장용종의 Chi-Square test에서 지방간이 있는 사람이 지 방간이 없는 사람보다 유의미하게 용종이 많이 발생하였다(p<.001). 각 요인별 상관관계를 보았을 때 지방간과 대장 용종간의 상관관계가 가장 높았다(p<.001). 다중회귀분석에서는 지방간(OR $3.80 ; 95 \%$ CI 1.93.-7.50), 공복 시 혈당 (OR 2.51; 95\% CI 1.12-5.62), 나이(OR 2.12; 95\% CI 1.27-3.54) 이 대장용종의 발생에 유의미하게 작용하였다. 이상 의 연구결과에서 초음파검사로 진단된 지방간이 대장용종의 발생에 있어 유의미한 영향력을 나타내어 지방간으로 진 단되었을 때에는 대장내시경검사를 좀 더 적극적으로 고려해보는 것이 좋을 것이다.

주제어 : 초음파, 지방간, 대장용종, 대장암, 대장내시경검사

Received 3 February 2014, Revised 4 March 2014

Accepted 20 March 2014

Corresponding Author:Cheong-Hwan Lim(Dept. of Health Care Hanseo)

Email:, 1ch116@hanseo.ac.kr

ISSN: $1738-1916$
(C) The Society of Digital Policy \& Management. All rights reserved. This is an open-access article distributed under the terms of the Creative Commons Attribution Non-Commercial License (http://creativecommons.otg/licenses/by-nc/3.0), which permits unrestricted non-commercial use, distribution, and reproduction in any medium, provided the original work is properly cited. 


\section{Introduction}

The changes of modern society have led to modern diseases such as obesity, insulin resistance syndrome, FLD and colorectal cancer. Medical check up programs at individual and national levels are developing rapidly for preventive medicine.

The usefulness of ultrasound has already made it a popular examination method in health checkup programs. This method is the common for imaging diagnosis of liver disease, particularly FLD. FLD was first diagnosed by ultrasound in most cases, but patients tend to easily overlook the diagnosis because they do not have serious subjective symptoms when they have FLD diagnoses. Colorectal cancer, which is rapidly increasing along with the FLD, is the third most frequently occurring disease among all cancers in South Korea, and it has been increasing by an average of 6.9\% annually from 1999 to 2008, overtaking the US and UK, which are current representative risky countries for colorectal cancer [1].

Many epidemiologic studies reported that insulin resistance syndrome is a factor increasing the occurrence of malignant tumors of the colon [2][3]. Currently, the most important method to prevent colorectal cancer is the early detection and removal of colorectal polyps, which are known as precursors of colorectal cancer [4]. The numbers of progressive adenoma and occurring polyps in the whole colon have been increased for the last 10 years, and the rate of patients having colon polypectomies is also increasing [5]. The correlation between adenomatous polyps and non-alcoholic fatty liver disease has been reported recently in South Korea, but there are few cases, and the consistency of the results is inadequate. The purpose of this research is aggressive recognition for fatty liver, and to satisfy the needs of ultrasonography and colonoscopy by analyzing the correlation between diagnosed fatty liver and colorectal polyps by ultrasonography.

\section{Method}

\subsection{Subject}

A total of 348 patients were selected as subjects from 380 adults who had colonoscopy and abdomen ultrasonography at the Digestive Internal Medical Center located in Cheongju, Chungbuk,from October 2012 to March 2013, excluding patients with acute and chronic liver disease or colon disease. The sex ratio of the subjects was 59.2\%(206) male and 40.8\% (142) female, and the average age of subjects was $51.51( \pm 10.95)$. $55.2 \%(192)$ of the subjects were diagnosed for fatty liver disease by ultrasonography and 50.3\%(175) subjects were diagnosed with colorectal polyps by colonoscopy.

\subsection{Ultrasonography}

The instrument used for abdomen ultrasonography was a Prosound SSD-4000(ALOKA, Japan). Subjects were fasted at least 6 hours before examination, and a convex probe of $5.0 \mathrm{MHz}$ was used by three skilled radiologists and sonographers who did not have information on the purpose of the examination and clinical pathological results. Fatty liver is classified into 4 stages from known 4 standards regarding liver brightness, hepatorenal echogenic contrast, deep attenuation, and vascular blurring. The number of subjects diagnosed with fatty liver disease was $55.22 \%(192)$, and the average age was 53.06. The distributions were the normal group 44.8\%(156), mild fatty liver $24.4 \%(85)$, moderate fatty liver $25.3 \%(88)$, and severe fatty liver 5.5\%(19). This research is only analyzed by the status of fatty liver for irregular distribution of subjects according to the degree of fatty liver.

\subsection{Colonoscopy}

The colonoscopy instrument used for the examination was a CF-Q260AL(Olympus optical Co., Japan). Following bowel preparation with $4 \mathrm{~L}$ of 
polyethylene glycol lavage solution, colonoscopy was performed by 3 endoscopy specialists until the last part of the distal colon. A subject was included in the polyp group if at least one polyp was present, regardless of number and size of the polyp. 175 subjects(50.3\%) were diagnosed with colorectal polyps, and the average age of the subjects was $53.80( \pm 10.33)$.

\subsection{Measurements and data}

The height and weight of each subject were measured by a skilled nurse with subjects only wearing a check up gown from the hospital. Blood was collected 8 hours after fasting, and blood pressure was measured in a sitting position 5 minutes after stabilization by a standard mercury sphygmomanometer. Abdominal obesity was considered for waist circumference over 85 $\mathrm{cm}$ for females and over $90 \mathrm{~cm}$ for males according to the abdominal obesity standard of the Korean Society for the Study of Obesity.

Cholesterol standards were $240 \mathrm{mg} / \mathrm{dL}$ of total cholesterol(TC) and $160 \mathrm{mg} / \mathrm{dL}$ of low-density lipoprotein cholesterol(LDL-C) according to the National Cholesterol Education Program Adult Treatment panel Phase III(NCEP-ATP III) modified guideline. Triglyceride(TG) standards were $150 \mathrm{mg} / \mathrm{dL}$, $40 \mathrm{mg} / \mathrm{dL}$ for males, and $50 \mathrm{mg} / \mathrm{dL}$ for females of high-density lipoprotein cholesterol (HDL-C), 140 mmHgof maximal systolic blood pressure, $90 \mathrm{mmHg}$ of diastolic blood pressure, and $111 \mathrm{mg} / \mathrm{dL}$ of blood sugar(glucose) in fasting according to the CNEP-ATP III guideline revised in 2004. The body mass index $\left(\mathrm{BMI}, \mathrm{kg} / \mathrm{m}^{2}\right.$ ) over $25 \mathrm{~kg} / \mathrm{m}^{2}$ was considered as obesity according to the Korean nutrition survey standard. The standards of liver function rate were AST 12-38 IU/L, ALT 7-41 IU/L, and GGT 9-58 IU/L.

\subsection{Data analysis}

The statistical analysis was performed with the SPSS program V.12.0 in Windows. The statistical results were presented as the mean \pm standard deviation. Statistical analyses included an independent t-test, X2-test, and Pearson's correlation analysis. The relationship of FLD with the presence of colorectal polyps was evaluated by multiple logistic regression analysis after adjustment for independent variables.

The $\mathrm{p}$ value under 0.05 was considered as statistically significant, and the significance level was $95 \%$.

\section{Results}

3.1 Baseline characteristics of the study participants

Among the 348 subjects in this study, 192 subjects(55.2\%) were diagnosed with fatty liver disease, and 173 subjects(49.7\%) were diagnosed with colorectal polyps. The average age of subjects who have polyps was $53.80( \pm 10.33)$, and the average age of subjects who did not have polyps was $49.53( \pm 11.71)$. The baseline characteristics of the mean values summarized are in [Table 1].

\subsection{Basic frequency of study participants} with risk factors of polyps

Polyps were found in 112 people(54.3\%) of 206 people(59.2\%) among male subjects, and 118 people ${ }^{1)}$ (57.8\%) of 204 people(58.6\%) with older age $(\mathrm{p}=0.036)(\mathrm{p}<0.001)$.

Also, polyps were found in 50 people(76.9\%) of 65 people(18.7\%) with a higher fasting glucose, 129 people(67.2\%) of 192 people(55.2\%) with FLD, 68 people(52.3\%) of 103 people(29.6\%) with higher triglycerides, and 44 people(66.7\%) of 66 people(19.0\%) with higher GGT. 63 people(36.3\%) had no polyps with fatty liver and 44 people(25.4\%) had no fatty liver with polyps. 
$<$ Table 1 $>$ Comparison of baseline characteristic of the study participants

\begin{tabular}{|c|c|c|c|}
\hline & variables & $\begin{array}{l}\text { without polyp } \\
n=175(50.3 \%)\end{array}$ & $\begin{array}{c}\text { polyp } \\
\mathrm{n}=173(49.7 \%)\end{array}$ \\
\hline \multirow{11}{*}{$\begin{array}{c}\mathrm{NL} \\
\mathrm{n}=156 \\
(44.8 \%)\end{array}$} & Age & $48.8 \pm 11.4$ & $52.9 \pm 11.7$ \\
\hline & $\mathrm{SBP}(\mathrm{mmHg})$ & $119.3 \pm 12.4$ & $121.4 \pm 12.8$ \\
\hline & $\mathrm{DBP}(\mathrm{mmHg})$ & $77.0 \pm 9.5$ & $76.7 \pm 8.8$ \\
\hline & $\mathrm{TC}(\mathrm{mg} / \mathrm{dL})$ & $187.7 \pm 37.3$ & $190.2 \pm 27.0$ \\
\hline & $\operatorname{AST}(\mathrm{mg} / \mathrm{dL})$ & $24.3 \pm 9.5$ & $23.1 \pm 9.0$ \\
\hline & ALT(mg/dL) & $24.2 \pm 11.7$ & $20.9 \pm 8.2$ \\
\hline & $\mathrm{rGT}(\mathrm{mg} / \mathrm{dL})$ & $29.9 \pm 21.1$ & $28.3 \pm 13.2$ \\
\hline & $\mathrm{WC}(\mathrm{cm})$ & $79.6 \pm 7.3$ & $79.3 \pm 8.0$ \\
\hline & $\mathrm{BMI}\left(\mathrm{kg} / \mathrm{m}^{2}\right)$ & $22.4 \pm 2.3$ & $22.6 \pm 2.4$ \\
\hline & TG(mg/dL) & $97.6 \pm 55.0$ & $106.5 \pm 48.3$ \\
\hline & $\mathrm{HDL}(\mathrm{mg} / \mathrm{dL})$ & $55.9 \pm 17.6$ & $54 \pm 13.2$ \\
\hline \multirow{13}{*}{$\begin{array}{c}\text { FLD } \\
\mathrm{n}=192 \\
(55.2 \%)\end{array}$} & LDL(mg/dL) & $110.5 \pm 34.3$ & $111.2 \pm 22.1$ \\
\hline & Age(years) & $50.9 \pm 12.2$ & $54.1 \pm 9.9$ \\
\hline & $\mathrm{SBP}(\mathrm{mmHg})$ & $127.2 \pm 18.2$ & $127.5 \pm 13.8$ \\
\hline & $\mathrm{DBP}(\mathrm{mmHg})$ & $82.6 \pm 11.1$ & $82.5 \pm 9.2$ \\
\hline & TC & $206.7 \pm 37.3$ & $207.6 \pm 37.6$ \\
\hline & AST & $26.0 \pm 9.4$ & $32.9 \pm 15.8$ \\
\hline & ALT & $32.3 \pm 18.2$ & $38.6 \pm 24.2$ \\
\hline & rGT & $48.3 \pm 35.9$ & $55.4 \pm 47.0$ \\
\hline & $\mathrm{WC}(\mathrm{cm})$ & $87.9 \pm 8.0$ & $90.7 \pm 7.8$ \\
\hline & $\mathrm{BMI}\left(\mathrm{kg} / \mathrm{m}^{2}\right)$ & $25.8 \pm 2.7$ & $26.0 \pm 2.8$ \\
\hline & TG & $153.9 \pm 104.6$ & $165.7 \pm 96.5$ \\
\hline & $\mathrm{HDL}$ & $52.3 \pm 16.0$ & $50.8 \pm 15.6$ \\
\hline & $\mathrm{LDL}$ & $124.6 \pm 37.5$ & $116.9 \pm 36.9$ \\
\hline
\end{tabular}

NL;normal liver FLD;fatty liver disease

WC;.waist circumference

SBP;Systolic blood pressure DBP;Diastolic blood pressure

Compared with normal subjects, the polyp group subjects were more likely to be men, and to have FLD, older age, higher BMI, WC, fasting glucose, TG, GGT, AST, and ALT < Table 2>

$<$ Table $2>$ baseline characteristic of the study participant with polyps

\begin{tabular}{|l|l|c|c|c|c|}
\hline \multicolumn{2}{|c|}{ Variable } & $\mathrm{n}(\%)$ & normal & $\begin{array}{c}\text { polyp: } \\
\mathrm{n}(\%)\end{array}$ & $\mathrm{p} *$ \\
\hline Gender & $\mathrm{M}$ & $206(59.2)$ & $94(45.6)$ & $112(54.4)$ & \\
& $\mathrm{F}$ & $142(40.8)$ & $81(57.0)$ & $61(43.0)$ & 0.036 \\
\hline Age & $<50$ & $144(41.4)$ & $89(61.8)$ & $55(38.1)$ & \\
& $\geq 50$ & $204(58.6)$ & $86(42.1)$ & $118(57.8)$ & $<0.001$ \\
\hline High & Yes & $140(40.2)$ & $54(38.6)$ & $86(61.4)$ & \\
BMI & No & $208(59.8)$ & $121(58.1)$ & $87(41.8)$ & 0.001 \\
\hline FLD & Yes & $192(55.2)$ & $63(32.8)$ & $129(67.1)$ & \\
& No & $156(44.8)$ & $112(71.8)$ & $44(28.2)$ & $<0.001$ \\
\hline Raised & Yes & $200(57.5)$ & $79(39.6)$ & $121(60.5)$ & \\
WC & No & $148(42.5)$ & $96(64.9)$ & $52(35.1)$ & $<0.001$ \\
\hline
\end{tabular}

\begin{tabular}{|l|l|c|c|c|c|}
\hline Raised & Yes & $65(18.7)$ & $15(23.0)$ & $50(77.0)$ & \\
glucose & No & $282(81.0)$ & $160(56.7)$ & $122(43.2)$ & $<0.001$ \\
\hline $\begin{array}{l}\text { Elevate } \\
\text { SBP }\end{array}$ & Yes & $53(15.2)$ & $22(12.6)$ & $32(17.9)$ & \\
\hline Elevate & Yes & $295(84.8)$ & $153(87.4)$ & $142(82.1)$ & 0.196 \\
DBP & No & $274(78.7)$ & $34(19.4)$ & $40(23.1)$ & \\
\hline Raised & Yes & $103(29.6)$ & $35(20)$ & $68(39.3)$ & \\
TG & No & $245(70.4)$ & $140(80)$ & $105(60.7)$ & $<0.001$ \\
\hline Raised & Yes & $47(13.5)$ & $23(13.1)$ & $24(13.9)$ & \\
TC & No & $301(86.5)$ & $152(86.9)$ & $149(86.1)$ & 0.843 \\
\hline Raised & Yes & $66(19.0)$ & $22(12.6)$ & $44(25.4)$ & \\
GGT & No & $282(81.0)$ & $153(87.4)$ & $129(74.6)$ & 0.003 \\
\hline Raised & Yes & $68(19.5)$ & $24(13.7)$ & $44(25.4)$ & \\
ALT & No & $280(80.5)$ & $151(86.3)$ & $129(74.6)$ & 0.007 \\
\hline Raised & Yes & $54(15.5)$ & $19(10.9)$ & $35(20.2)$ & \\
AST & No & $294(84.5)$ & $156(89.1)$ & $138(79.8)$ & 0.019 \\
\hline Low & Yes & $129(37.1)$ & $100(57.1)$ & $119(68.8)$ & \\
HDL & No & $219(62.9)$ & $75(42.9)$ & $54(31.2)$ & 0.055 \\
\hline Raised & Yes & $309(88.8)$ & $24(13.7)$ & $15(8.7)$ & \\
LDL & No & $39(11.2)$ & $151(86.3)$ & $158(91.3)$ & 0.221 \\
\hline
\end{tabular}

3.3 The association of FLD and polyps by the $\mathrm{X}^{2}$-test

According to the conditions of FLD, there are differences in the presence of colorectal polyps ( $p$ <.001). 129 subjects(74.6\%) had FLD among the 173 subjects who had polyps, and 44 subjects(25.4\%) had polyps among the 156 subjects who did not have FLD $(\mathrm{p}<.001),<$ Table3>.

$<$ Table $3>$ The association of FLD and colorectal polyps

\begin{tabular}{|c|c|c|c|c|}
\hline \multirow{2}{*}{} & \multicolumn{3}{|c|}{ colorectal polyp } & \multirow{2}{*}{$\mathrm{x}^{2}$} \\
\cline { 2 - 4 } & $\begin{array}{c}\text { polyp } \\
\mathrm{n}(\%)\end{array}$ & $\begin{array}{c}\text { normal } \\
\mathrm{n}(\%)\end{array}$ & $\begin{array}{c}\text { total } \\
\mathrm{n}(\%)\end{array}$ & \\
\hline \multirow{3}{*}{ FLD } & 129 & 63 & 192 & \\
\hline & $(74.6)$ & $(36.3)$ & $(55.2)$ & \\
NL & 44 & 112 & 156 & 52.32 \\
& $(25.4)$ & $(64)$ & $(44.8)$ & $(\mathrm{p}<$ \\
total & 173 & 175 & 348 & $0.001)$ \\
\hline
\end{tabular}

*By the chi-square test at $\mathrm{a}=0.05$

NL;normal liver FLD;fatty liver disease

\subsection{Correlation degree of the risk factors of polyps}

Correlation analysis was used with the variables which were significant in the univariate analysis of the prevalence of polyps. Correlation coefficients were the 
highest in $\mathrm{FLD}(\mathrm{r}=0.39, \mathrm{p}<.001)$, followed by $\mathrm{FBC}(\mathrm{r}$ $=0.26, \mathrm{p}<.001), \mathrm{WC}(\mathrm{r}=0.25, \mathrm{p}<.001), \mathrm{TG}(\mathrm{r}=0.21, \mathrm{p}$ $<.001)$, age $(\mathrm{r}=0.19, \mathrm{p}<.001), \quad \mathrm{GGT}(\mathrm{r}=0.16, \mathrm{p}=.002)$, $\operatorname{ALT}(\mathrm{r}=0.15, \quad \mathrm{p}=.006), \quad \operatorname{AST}(\mathrm{r}=0.13, \quad \mathrm{p}=.016)$, $<$ Table4 $>$.

\begin{tabular}{|c|c|c|c|c|c|c|c|c|c|c|}
\hline & Age & WC & BMI & FBS & $\mathrm{FL}$ & $\mathrm{TG}$ & AST & ALT & GGT & $P$ \\
\hline Age & 1 & & & & & & & & & \\
\hline WC & 0.10 & 1 & & & & & & & & \\
\hline BMI & 0.01 & 0.50 & 1 & & & & & & & \\
\hline FBS & 0.17 & 0.2 & 0.23 & 1 & & & & & & \\
\hline FL & 0.09 & 0.49 & 0.49 & 0.27 & 1 & & & & & \\
\hline $\mathrm{TG}$ & 0.10 & 0.19 & 0.24 & 0.25 & 0.31 & 1 & & & & \\
\hline AST & 0.19 & 0.11 & 0.05 & 0.06 & 0.15 & 0.11 & 1 & & & \\
\hline ALT & 0.10 & 0.20 & 0.26 & 0.14 & 0.28 & 0.25 & 0.47 & 1 & & \\
\hline GGT & 0.03 & 0.22 & 0.26 & 0.16 & 0.32 & 0.3 & 0.28 & 0.40 & 1 & \\
\hline$P$ & $0.19^{* *}$ & $0.25^{* *}$ & $0.19^{* *}$ & $0.26^{* *}$ & $0.39^{* *}$ & $0.21^{* *}$ & $0.13^{*}$ & $0.15^{* *}$ & $0.16^{* *}$ & 1 \\
\hline
\end{tabular}

*Statistically significant difference by Pearson's correlation coefficient

3.4 Relationship with the risk factors for polyps by the multiple logistic regression analysis

Multiple regression analysis was conducted with each variable that has effective meanings in the occurrences of colorectal polyps in univariate analysis. Multivariate analysis results showed the following odds ratios for $\mathrm{FLD}(\mathrm{OR}$ 3.80; 95\% CI 1.93.-7.50) , $\mathrm{FBS}(\mathrm{OR}$ 2.51; 95\% CI 1.12-5.62), and older age(OR 2.12; 95\% CI 1.27-3.54), which were significantly effective to the occurrence of colorectal polyps.

$<$ Table 5> Risk for colorectal polyps by multiple logistic regression analysis Digital

\begin{tabular}{|c|c|c|c|c|}
\hline & & \multicolumn{2}{|c|}{$95 \%$ CI } & \multirow{2}{*}{ P* } \\
\cline { 3 - 4 } Variable & OR & Lower & Upper & \multirow{2}{*}{0.025} \\
\hline FG(mg/dL) & & & & \\
\hline$<111$ & 1 & & & \multirow{2}{*}{$<0.001$} \\
\hline$\geq 111$ & 2.51 & 1.12 & 5.62 & \\
\hline FLD & & & & \\
\hline Absence & 1 & & & \multirow{2}{*}{0.004} \\
\hline Presence & 3.80 & 1.93 & 7.50 & \\
\hline Age & & & & \\
\hline$<50$ & 1 & & & \\
\hline$\geq 50$ & 2.12 & 1.27 & 3.54 & \\
\hline
\end{tabular}

Adjusted for age, gender OR;odds ratio CI;confidence interval FG; fasting glucose FLD; fatty liver disease

\section{Conclusions and Discussion}

The most reliable diagnosis method for fatty liver is liver biopsy, but this is not a common medical method. Ultrasonography is very sensitive for the recognition of fatty degeneration of liver tissue. Because ultrasound has excellent sensitivity and is less expensive compared with $\mathrm{CT}$, it has become a common health screening method. Also, there is no radiation risk. The incidence of FLD is likely to rise further compared to the past, and colorectal cancer is a typical westernized cancer with a rapid tendency of increasing with obesity.

For the adenoma-carcinoma sequence theory in which adenomatous polyps proceed to cancer, much research has been performed since it was first reported in 1951[6].

The time for malignant transformation from adenoma to cancer is about 5 to 15 years, and over $95 \%$ of colorectal cancer is a result of adenomatous polyps. According to the results of comparison between diameter and pathological expression for endoscopic treatment performed for cancer, a small lesion with size less than $5 \mathrm{~mm}$ showed $80.8 \%$ adenoma, $18.6 \%$ hyperplastic polyp, and 0.6\% malignant polyp [7] Hyperplastic polyps turning into colorectal cancer, unlike adenomatous polyps, are controversial. However, the clinical importance of hyperplastic polyps cannot be ignored for histological malignant tumors found in hyperplastic polyps. In addition, risk factors of hyperplastic polyps and adenomatous polyps had no difference, and smoking particularly showed a higher prevalence rate in the analysis of colorectal polyps and life habits.

Colorectal cancer has high relation with metabolic syndromes such as obesity, hyperlipidemia, and glucose in the process of carcinogenesis. After association between obesity and colorectal cancer was established, there has been much research on the relations between colorectal polyps and obesity [8-11]. BMI is used as an 
obesity index, but consistent data in the prevalence rate of polyps is not found [12][13]. In the other words, BMI alone cannot be a predictive factor for polyps. This would be an issue for the suitability of BMI in the degree of obesity. Meanwhile, all correlations in the number and size of polyps and BMI were consistent, which means the number and size of polyps simultaneously increased as the BMI increased. In this study, BMI in the prevalence of polyps showed a significant relationship with the onset. The hepatic steatosis index of non-alcoholic fatty liver also considered obesity as an important factor [14]. According to a research report on NAFLD of non-obesity patients, higher weight compared to the past caused a higher rate of fatty liver and many abnormal factors of metabolic syndrome, even with a normal obesity index[15][16]. FLD is associated with risk factors of metabolic syndrome and has higher positive predictive values than body mass index(BMI) and waist circumference [17]. NAFLD could be an early clue to forecast the metabolic disorders in adults who are not obese. NAFLD itself increases the atherosclerosis occurrence risks by $55 \%$ in the absence of other risk factors [18]. FLD had the highest impact on the occurrence of polyps in the present report. Fasting glucose, triglycerides, and obesity appeared as risk factors for polyps, which were similar to the results of other studies. Colorectal cancer is highly associated with obesity, hyperlipidemia, and metabolic syndrome in the process of carcinogenesis.

In the present report, drinking and the components of polyps were not considered. Similar results were obtained from other studies regarding the prevalence of polyps. The reason is estimated to be the similar involvement of the metabolic syndrome in FLD and NAFLD, and the highest distribution of adenomatous colorectal polyps[19].

In one study associated with the metabolic syndrome that occupied $69.9 \%$ of mild FLD, FLD was not mentioned as a significant factor for metabolic syndrome[20]. Additionally, in another study, NAFLD was mentioned not to have a relationship with the prevalence of colorectal adenomas, showing different opinions from existing study results [21]. Analysis in degrees of FLD was not considered in those studies. The analysis of FLD according to the degrees was not considered in the present report as well. In the cases of highly occupied mild fatty liver, the relation between fatty liver and colorectal polyps could have differences in the results of this study. Therefore, more thorough research for the relation of fatty liver degree by colorectal polyps and ultrasonography is needed in the future. In addition, more complex and broad research analysis with various environmental factors is needed

The World Health Organization(WHO) said that 1/3 of cancer cases are preventable, and 1/3 are curable when diagnosed early. Colorectal cancer treatment is limited in terms of time, and diagnosis of the earliest colorectal cancer is diagnosable by colonoscopy [22][23].

Colorectal polyps in other research showed frequency increases in males and with age. Glucose, smoking, and hyperlipidemia were risk factors among subjects with no subjective symptoms[24]. This research found polyps in $54.4 \%$ of males and $57.8 \%$ in those with age over 50. Often, colorectal polyps have no significant associative correlation with subjective symptoms.

The divergence between incidence and mortality rates would suggest that possible explanations may lie in improved accessibility to endoscopy increased early detection with a corresponding shift to an earlier disease stage[25][26]. This trend is having important consequences in regard to disease prevalence and burden of care

Colonoscopy should actively be encouraged for earlier-stage diagnosis of colorectal cancer, and ultrasonography will also continuously increase and expand for its usability. Since clinically common fatty liver increases the incidence of colorectal polyps, a 
more positive attitude is needed for colonoscopy when diagnosing fatty liver by ultrasound.

\section{References}

[1] http://kostat.go.kr/portal/korea/index.action

[2] Yong Kyun Cho, Relationship of non-alcoholic fatty liver disease to colorectal adenomatous polyps, kor.J Gastroenterology and Hepatology, pp. 562 567, 2010

[3] Sidney Winawer, Colorectal cancer screening and surveillance: Clinical guidelines and rationale Update based on new evidence, vol. 124, no. 2, pp. 544-560, 2003

[4] Ann G, Colonoscopic Polypectomy and Long-Term Prevention of Colorectal-Cancer Deaths", N Engl J Med, 366, pp.687-696, 2012

[5] Adachi miki, Adenoma-carcinoma sequence, Jap. Gastroenterological Surgery, vol. 28, no. 5, pp.547-552, 2005

[6] Jackman RJ, The adenoma-carcinoma sequence in cancer of the colon. Surg Gynecol Obset, 93. pp.327-330. 1951

[7] Bae TS, Clinical Significance of the Colorectal Polyps, vol. 16, no. 4, pp.247-253, 2000

[8] Oh sw. Effect of excess weight on cancer incidence depending on cancer sites and histologic finding among men: Korea National Health Insurance Coporation Study, J Clin Oncol, vol. 23. pp.4742-4754. 2005

[9] Frezza EE. Influence of obesity on the risk of developing colon cancer, Chiriva Internati M,Gut, 55. pp.285-291. 2006

[10] Zhang H, Long term body weight fluctuation is associated with metabolic syndrome indepen -dent of current body mass index among Japanese men, Circ J, vol. 69, no. 1, pp.13-18, 2005

[11] Jeong Hoon Ji, Clinicopathologic Study of Colorectal Polyps and Obesity in Korean Adults, Kor. J Gastroenterol, vol. 49, no. 1, pp. 10-17, 2007
[12] Chang-Sup Kim, Association of Obesity and Left Colonic Adenomatous Polyps in Korean Adult Men, J. Prev Med Public Health, vol. 38, no.4, pp.415-419, 2005

[13] Ji Hyung Nam, Clinical Characteristics and Risk Factors of Colon Polyps in Gyeongju and Pohang Area, Korean J. of Gastroenterology, vol. 52, no. 3 pp.142-149, 2008

[14] Jeong-Hoon Lee, Hepatic steatosis index: A simple screening tool reflecting nonalcoholic fatty liver disease, Digestive and Liver Disease, vol. 42, no. 7, pp.503-508, 2010

[15] Sun Hee Lee, Relation between Weight History during Adult Period and Non-alcoholic Fatty Liver Disease in Non-obese Men, J. Korean Society for the Study of Obesity, vol.18, no.2, pp.53-58, 2009

[16] Deok Yun Ju, The influence of waist circumference on insulin resistance and nonalcoholic fatty liver disease in apparently healthy Korean adults, Clinical and Molecular Hepatology, vol. 19, no. 2, pp. 140 $-147,2013$

[17] Fan JG,. Epidemiology of non-alcoholic fatty liver disease in China, J Hepatol, vol. 50, no.1, pp. 204 $-210,2009$

[18] Su yeon choi, Nonalcoholic fatty liver disease as a risk factor of cardiovascular disease;relation of non-alcoholic fatty liver disease to carotid atherosclerosis, Kor. J. hepatology, vol. 14, pp.77-88, 2008

[19] Kotronen A. Non-alcoholic and alcoholic Fatty Liver Disease two Diseases of Affluence associated with the Metabolic Syndrome and Type 2 Diabetes: the FIN-D2D Survey, BMC Public Health, 10.10.1. 2010

[20] Cheol Soon Im, Risk Factors Associated with Metabolic Syndrome in Ultrasonographic Fatty Liver, J. Korean Society for the Study of Obesity, vol. 17, no .3, pp.124-131, 2008

[21] Won Gue Choi, Association between Nonalcoholic Fatty Liver Disease and Colorectal Adenoma in Health Screen Examines, Kor. J. Gastrointest 
Endosc, vol. 41, no. 4, pp.201-207, 2010

[22] Sin hyang sook, analysis study of incidence and risk factors of colon polys observed by colonoscopy in health promotion center, J Gastroenterology and Hepatology, vol. 25, no. 2, pp.352-356, 2005

[23] G. López-Abente, Changes in colorectal cancer incidence and mortality trends in Spain, analas of Oncology , vol 21, no. 3, pp.76-82, 2010

[24] Yamada $\mathrm{TF}$ et al. fatty liver predicts impaired fasting glucose and type 2 diabetes-mell itus in Japanese undergoing a health checkup. J Gastroenterol Hepatol, vol 25, pp.352-356, 2010

[25] Jong Hoon Lee, Research Update Screening : Test for Colorectal Cancer: Colonoscopy and Fecal Immunochemical Test, Korean J. Gastroenterology, vol. 59. No. 5, pp.389-391. 2012

[26] Jang YS, Retrospective study of 125 cases colon polyp patients who underwent colo -noscopic polypectomy, Korean J Gastrointest Endosc, vol 21. pp.608-613, 2000

이 혜 남(Hye Nam Lee)

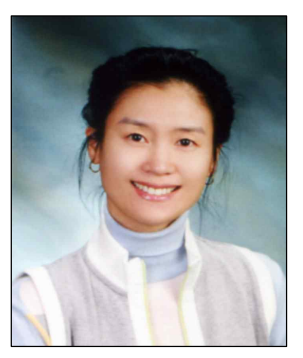

- 2009년 2월 : 호원대학교 디지탈영 상정보학과(이학사)

- 2011년 8월 : 한서대학교 방사선과 (방사선학석사)

- 2014년 2월 : 한서대학교 보건의료 학과(보건학박사)

- 2006년 3월 현재: 원광보건대학교 방사선과 교수

- 관심분야 : 방사선학, 초음파학

•E-Mail : hnlee@wu.ac.kr

임 청 환(Chung-Hwan, Lim)

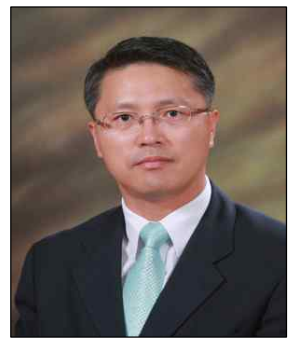

- 1997년 8월: 단국대학교 보건행정학 과(보건학석사)

- 2005년 2월: 경원대학교 의료경영학 과(보건학박사)

- 2001년 3월 현재 : 한:서대학교 방 사선학과, 보건의료학과 교수

- 관심분야 : 방사선학, 보건의료학

•E-Mail : LCH116@hanseo.ac.kr
정 홍 량(Hong-Ryang, Jung)

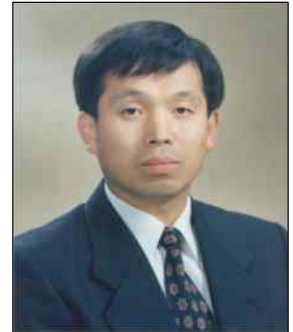

- 1995년 2월 : 단국대학교 보건행정 학과(보건학석사)

- 2004년 8월 : 순천향대학교 환경보 건학과(보건학박사)

- 1999년 3월 현재 : 한서대학교 방 사선학과, 보건의료학과 교수 - 관심분야 : 방사선학, 보건역학

·E-Mail : hrjung@hanseo.ac.kr 